\title{
Sustainable Agriculture: Self-Reported Knowledge among Agricultural Students
}

\author{
Nurul Husna AbRazak and Abdullah Mat Rashid* \\ Department of Science and Technical Education, Universiti Putra Malaysia, Serdang, Selangor, Malaysia; \\ husna_razak92@yahoo.com,abmr@upm.edu.my
}

\begin{abstract}
Background/Objectives: Usage of pesticide, herbicide, inorganic fertilizers in conventional agriculture practices dramatically turn out to be more profitable orientation rather than responsible. Also, natural resources had been settler without preserves and conserves. In contrast, sustainable agriculture practices have proven conserves and preserve water, plant, and land. Furthermore, are environmentally healthy, economically viable and socially acceptable. However, findings from different studies reveal that, communities including younger generation do not have enough knowledge and understanding on sustainable agriculture. This study is focusing on self-reported knowledge on sustainable agriculture practices among students in agricultural program. Methods/Statistical Analysis: This study utilized survey design. Samples were randomly selected among students in agricultural programs in one of the Malaysian university. The data was collected using previous modified instrument that measure self-reported knowledge on sustainable agriculture practices. Findings: The result shows that the students' self-reported knowledge on sustainable agriculture was at a moderate level. Applications/Improvements: This result can be used to improve students understanding and the betterment of sustainable agriculture curriculum.
\end{abstract}

Keywords: Agricultural Education, Conventional Agriculture, Environmental Pollution, Technical and Vocational Education and Training (TVET)

\section{Introduction}

Conventional agriculture practices usually are focusing on the profit and the products but not paying much attention to the ecosystem or environmental health. This matter has been contributed to environmental pollution. Soil pollution, for instance, caused by a high presence of toxic chemicals due to the high use of pesticides, fertilizers and herbicides has exposed human health to a high risk and put the ecosystem in a danger situation ${ }^{1}$.

Sustainable agriculture is seen to be one of the ways to overcome this problem. $\operatorname{In}^{2-4}$ stated that, the three main objectives of sustainable agriculture are environmentally healthy, economic profitability, and social equity. Sustainable agriculture practices and principles ensure sufficient food supply in a healthy way for the current and future generation by using available natural resources in optimum ways ${ }^{5}$.
In Malaysia, some of the practices of sustainable agriculture are crop rotation and no-tillage. These practices do not allow for any cultivation or production of a particular crop on the same land for a prolonged period of time.

Furthermore, it not just protects the soil from excessive use of natural resources but also preserve the soil from soil erosion and meet the objective of environmental sustainability where will protects the nature. FAO (2018), such practices that fully exploit natural processes, i.e. nutrients recycle where the plants fix their own nitrogen and achieving a balance between predators and pests, that will reduce the reliance on inputs (chemical pesticides and mineral fertilizers). This also will reduce operation costs and meet the objective of economic sustainability. Sustainable agriculture also meets the objective of social sustainability with developing rural communities by establish small farms and diversify the farming systems. 
This practice not just helps the farmers to thrive but also secure their continued vitality.

In order to practice sustainable agriculture students who going too involved in agriculture required to have awareness, skill and knowledge. However, results from previous studies show that the participants do not have enough knowledge on sustainable agriculture. In $\mathrm{I}^{6,7}$ found out that students still have moderate knowledge in sustainable agriculture. Therefore, a proper sustainable agriculture education is essential that will increase their awareness, improve their skills and knowledge.

\subsection{Sustainable Agriculture in Agricultural Education}

Teachers and community play a vital role to ensure students that involve in agriculture and the future farmers to practice sustainable agriculture. According to ${ }^{8}$ agriculture teachers with vast knowledge on sustainable agriculture will influence students to practice sustainable agriculture. Teachers have capability to aspire in elevate students' knowledge?

In ${ }^{10}$ found out that some challenges faced to integrate sustainable agriculture in agricultural education are lack of understanding on sustainable agriculture technology, lack of teaching skills for sustainable agriculture, lack of marketing for potential courses of sustainable agriculture, lack of textbooks on sustainable agriculture and teacher qualification for teaching sustainable agriculture. According to ${ }^{11}$ curriculum-based intervention is one of the ways to prepare students for the industry. Since the purpose of agriculture education is to promote learning on agricultural, students should be guides and emphasis on learning by doing in order to improve knowledge and skills through curriculum content. Curriculum-base intervention focuses on design or selection of teaching strategies or methods that increase the likelihood of learning. Integrating the technical and scientific elements of sustainable agriculture will help in improving the quality of agricultural education curriculum to meet the needs of students in preparing for labour entry in agriculture industry.

Researchers found out that curriculum based on current problems can improve the information, attitudes and behaviour of the students and cause them to feel more responsible to the environmental issues $\frac{12-14}{}$. Researchers also found out that the positive attitudes of youth to the environment can be nurtured at the beginning of education ${ }^{15}$. This suggests that, if the students are given a clear understanding and knowledge of sustainable agriculture at the earliest stage, it will help the students to understand sustainable agriculture better. A comprehensive understanding on social, economic and environmental benefits is required to create a sustainable agriculture throughout the system ${ }^{\frac{16}{6}}$. Through a good knowledge and understanding it will be easier for sustainable agriculture to be absorbed into agricultural education systems.

Students think sustainable agriculture has the potential to have a positive impact on agriculture. This is because, sustainable agriculture has the potential to influence the environmental, economic and social dimensions in agriculture sector. This is where the curriculum specialists and teachers can develop teaching and learning opportunities where students can expand their knowledge and understanding on sustainable agriculture practices. As the research yields new findings, educators should integrate appropriate technologies into the school curriculum allowing students to develop the knowledge that will help them realize the potential and benefits of sustainable agriculture.

Thus, the objective of this study is to identify agricultural science student perceptions on self-reported knowledge and the benefits of sustainable agriculture practices. In this study, the independent variables used are student's self-reported knowledge and student perceptions on the benefits of sustainable agriculture practices while the dependent variables is the student expectations on sustainable agriculture practices.

\section{Methodology}

The research utilized survey design to see the perceptions of the students on sustainable agriculture. According to ${ }^{17}$, survey design can be used to see the perceptions of the sample. A total of 160 students were randomly chosen as sample of this study from different agricultural programs at one of the higher institutions in Malaysia.

The researcher modified the instrument to measure self-reported knowledge on sustainable agriculture practices to suit with the current practices of sustainable agriculture in Malaysia. The reliability of the questionnaire was estimated by calculating Cronbach's alpha, which was 0.893 . The face and content validity 
of the instrument was also conducted. The instrument used consists of four sections. Section one discussed on demographic of respondents like gender, race, age, when the first time they learn agriculture, academic level and current semester. Section two discussed on students' selfreported knowledge on sustainable agriculture practices. Section three discussed on student perceptions on the benefits of sustainable agriculture practices and section four discussed on student expectations on sustainable agriculture practices. Four-point scale, scores 1 to 4 , where 1 represent strongly disagree, 2 represent disagree, 3 represent agree and 4 represent strongly agree was used for every items. The data collected such as frequency, percentage, mean and standard deviation was analyzed to identify the perceptions of the students on sustainable agriculture.

\section{Finding}

Table 1 shows the frequency and percentage of students demographics such as gender, race, age, when the students learn agriculture for the first time, academic level and current semester. From the results, 60 students were male and 100 students were female. The majority of the sample was Malay with 146 students followed by Chinese, 9 students and others, 5 students.

Table 1. Demographics of sample of 160 students in agricultural program

\begin{tabular}{|c|c|c|}
\hline & Frequency & Percentage $(\%)$ \\
\hline \multicolumn{3}{|l|}{ Gender } \\
\hline Male & 60 & 37.5 \\
\hline Female & 100 & 62.5 \\
\hline \multicolumn{3}{|l|}{ Race } \\
\hline Malay & 146 & 91.3 \\
\hline Chinese & 9 & 5.6 \\
\hline Others & 5 & 3.1 \\
\hline \multicolumn{3}{|l|}{ Age } \\
\hline $21-23$ & 130 & 81.3 \\
\hline $24-26$ & 25 & 15.6 \\
\hline $27-29$ & 5 & 3.1 \\
\hline \multicolumn{3}{|c|}{ When you learn agriculture for the first time } \\
\hline $3-4$ years ago & 90 & 56.3 \\
\hline $5-6$ years ago & 50 & 31.3 \\
\hline $7-8$ years ago & 20 & 12.5 \\
\hline
\end{tabular}

\begin{tabular}{|c|c|c|}
\hline \multicolumn{3}{|c|}{ Academic Level } \\
\hline $\begin{array}{l}\text { Upper high } \\
\text { school }\end{array}$ & 30 & 18.8 \\
\hline Matriculation & 60 & 37.5 \\
\hline Diploma & 30 & 18.8 \\
\hline Foundation & 40 & 25.0 \\
\hline \multicolumn{3}{|c|}{ Current Semester } \\
\hline $\begin{array}{l}\text { Third-fourth } \\
\text { semester }\end{array}$ & 80 & 50.0 \\
\hline $\begin{array}{l}\text { Fifth-sixth } \\
\text { semester }\end{array}$ & 80 & 50.0 \\
\hline
\end{tabular}

\subsection{Self-Reported Knowledge, Student} Perceptions on the Benefits and Expectations of Students on Sustainable Agriculture Practices

Table 2 exhibits the mean and standard deviation for students' self-reported knowledge on sustainable agriculture practices. Items that focusing on plants and animals selection, biological control, integrating livestock with crops, maintain water quality and supply, agroforestry and use renewable energy sources such as wind, solar and biomass show the highest mean i.e., 3.37 ( $\mathrm{S} . \mathrm{D}=0.48$ ). Meanwhile, item that focusing on planting cover crops shows the lowest mean which is 2.91 $(\mathrm{S} . \mathrm{D}=0.42)$. Overall, students' self-reported knowledge on sustainable agriculture practices was at a moderate level.

Table 2. Mean and standard deviation for students' self-reported knowledge on sustainable agriculture practices

\begin{tabular}{|l|c|c|}
\hline Items & Mean & $\begin{array}{c}\text { Standard } \\
\text { Deviation }\end{array}$ \\
\hline Crop rotation & 3.29 & 0.47 \\
\hline Planting cover crops & 2.91 & 0.42 \\
\hline Plants and animals selection & 3.37 & 0.48 \\
\hline Biological control & 3.37 & 0.48 \\
\hline No-tillage & 2.94 & 0.24 \\
\hline Integrating livestock with crops & 3.37 & 0.48 \\
\hline Maintain water quality and supply & 3.37 & 0.48 \\
\hline Integrated pest management & 3.06 & 0.24 \\
\hline Agroforestry & 3.37 & 0.48 \\
\hline $\begin{array}{l}\text { Use renewable energy sources } \\
\text { such as wind, solar and biomass }\end{array}$ & 3.37 & 0.48 \\
\hline Mean & 3.24 & 0.42 \\
\hline
\end{tabular}


Table 3 shows the mean and standard deviation for student perceptions on the benefits of sustainable agriculture practices. Item that focusing on safer food shows the highest mean which is 3.38 ( $. \mathrm{D}=0.49$ ). Meanwhile item that focusing on reduced need for off-farm inputs shows the lowest mean which is 2.51 $(S . D=0.69)$. Overall, student perceptions on the benefits of sustainable agriculture practices were at a moderate level.

Table 3. Mean and standard deviation for student perceptions on the benefits of sustainable agriculture practices

\begin{tabular}{|l|c|c|}
\hline \multicolumn{1}{|c|}{ Items } & Mean & $\begin{array}{c}\text { Standard } \\
\text { Deviation }\end{array}$ \\
\hline Protects underground water. & 3.25 & 0.43 \\
\hline Conservation of soil. & 3.25 & 0.43 \\
\hline Reduced use of chemicals. & 3.25 & 0.43 \\
\hline Safer food. & 3.38 & 0.49 \\
\hline Protection of wildlife. & 3.25 & 0.43 \\
\hline Protection of woodlands. & 3.25 & 0.43 \\
\hline Reduced pollution. & 3.25 & 0.43 \\
\hline Reduced use of petroleum energy. & 3.25 & 0.43 \\
\hline Reduced need for off-farm inputs. & 2.51 & 0.69 \\
\hline Mean & 3.18 & 0.46 \\
\hline
\end{tabular}

Table 4 shows the mean and standard deviation of student expectations on sustainable agriculture practices. Item that focusing on healthy environment shows the highest mean which is $3.37(\mathrm{~S} . \mathrm{D}=0.48)$. Meanwhile the item that focusing on enhance the environmental quality and natural resources shows the lowest mean which is 2.91 $(S . D=0.29)$. Overall, student expectations on sustainable agriculture practices were at a moderate level.

Table 4. Mean and standard deviation for student expectations on sustainable agriculture practices

\begin{tabular}{|l|c|c|}
\hline Items & Mean & $\begin{array}{c}\text { Standard } \\
\text { Deviation }\end{array}$ \\
\hline $\begin{array}{l}\text { An integrated system of } \\
\text { plant and animal production } \\
\text { practices. }\end{array}$ & 3.19 & 0.39 \\
\hline $\begin{array}{l}\text { Focusing on healthy } \\
\text { environment. }\end{array}$ & 3.37 & 0.48 \\
\hline $\begin{array}{l}\text { Integrate natural biological } \\
\text { cycles and controls. }\end{array}$ & 3.19 & 0.39 \\
\hline
\end{tabular}

\begin{tabular}{|l|c|c|}
\hline Items & Mean & $\begin{array}{c}\text { Standard } \\
\text { Deviation }\end{array}$ \\
\hline $\begin{array}{l}\text { Enhance the environmental } \\
\text { quality and natural resources. }\end{array}$ & 2.91 & 0.29 \\
\hline $\begin{array}{l}\text { Make the most efficient use } \\
\text { of nonrenewable resources } \\
\text { and on-farm resources. }\end{array}$ & 2.95 & 0.35 \\
\hline Mean & 3.12 & 0.38 \\
\hline
\end{tabular}

\section{Discussion}

The level of knowledge of the students on sustainable agriculture is at moderate level. It is important for the students to understand how sustainable agriculture can help reduce current problems to the environment for betterment. A good curriculum is one of the ways to instil students with awareness, knowledge and understanding about sustainable agriculture. TVET institutions must revise continually their curriculum to ensure improvement in tune to the need for environmental awareness. Through a better and improve curriculum, the students can get as many knowledge and input as possible for them to practice in the real world. For a successful implementation of sustainable agriculture, student's knowledge is vital. Only by a better understanding and knowledge, a successful sustainable agriculture can be practiced.

This study has focussed on students' self-reported knowledge, benefits of sustainable agriculture practices and student expectations on sustainable agriculture practices. Conventional agriculture has caused a great loss to the Planet over the time. Excessive use of inorganic fertilizer and chemical control are the few examples of harmful practices of conventional agriculture. This practices not only cause the environmental pollution but also increasing the cost of operation for the farm. By applying the sustainable agriculture practices, it can help in reducing the environment pollution and cost of future operational cost. One of the example of sustainable agriculture practices is by planting cover crop. By planting cover crop, the soil will trap enough moisture and some of the cover crop will trap enough nutrients for the plant growth. This symbiosis will save the water need and reduce the need to use the inorganic fertilizer. Students should be taught on how the sustainable agriculture practices can help the environment. Every sustainable 
agriculture practices have their own purpose and benefits for the environment as a whole ${ }^{18}$.

Therefore, agriculture education should emphasize on the benefits of sustainable agriculture practices to the agriculture sector. A proper education and training must be given to the students so that they can adopt and adapt the sustainable agricultural practices into the real world. Agriculture education should be on par with the current development. The world is changing every moment and our educational system must be upgraded, so that our students will get the best out of the education system. In this study and the previous study, there is not much change in the agriculture education. Students still not have adequate knowledge on sustainable agriculture. Therefore, agriculture education plays a vital role to spread the benefit of sustainable agriculture among the students. There must be an improvement in teaching and learning process in order for the knowledge to reach the students.

\section{Conclusion}

Based on the results, students' knowledge on sustainable agriculture still showed less improvement. Thus, there is a need for the educational institutions like TVET institutions which contributes semi and skills workforce focusing on continually improving their graduates and curriculum. To produce workforce that refuse practices that cause pollution, it is suggest teaching current students with practices of sustainable agriculture. Agriculture education system must be always up to date, so that students can improve and upgrading their knowledge and skills. Teachers also play a vital role to make sure the students get as many as knowledge and ideas on sustainable agriculture as possible. Teaching and learning process should include in explaining the concept of sustainable agriculture properly and correctly. Current students are the generation that can make a change on the harmful conventional agriculture practices towards a sustainable agriculture practices.

\section{References}

1. The Food and Agriculture Organization (FAO). Date accessed: 2018. http://www.fao.org/publications/sofa/en/.

2. Rigby D, Cáceres D. Organic farming and the sustainability of agricultural systems, Agricultural Systems. 2001; 68(1):21-40. https://doi.org/10.1016/S0308$521 \mathrm{X}(00) 00060-3$.
3. LeeDR. Agricultural sustainability and technology adoption: Issues and policies for developing countries, American Journal of Agricultural Economics. 2005; 87(5):1325-34. https://doi.org/10.1111/j.1467-8276.2005.00826.x.

4. Wheeler SA. Exploring professional attitudes towards organic farming, genetic engineering, agriculture sustainability and research issues in Australia, Journal of Organic Systems. 2008; 3(1):37-56.

5. Al-Subaiee SS, Yoder EP, Thomson JS. Extension agents' perceptions of sustainable agriculture in the Riyadh Region of Saudi Arabia, Journal of International Agricultural and Extension Education. 2005; 12(1):5-14. https://doi. org/10.5191/jiaee.2005.12101.

6. Williams DL. Students' knowledge of and expected impact from sustainable agriculture, Journal of Agricultural Education. 2000; 41(2):19-24. https://doi.org/10.5032/ jae.2000.02019.

7. Agahi H, Moradi K, Afsharzade N. Agricultural graduate students' attitudes towards sustainable agriculture: A case, Annals of Biological Research. 2012; 3(8):4007-11.

8. Muma M, Martin R, Shelley M, Holmes L. Sustainable agriculture: Teacher beliefs and topics taught, Journal of Sustainable Agriculture. 2010; 34(4):439-59. https://doi. org/10.1080/10440041003680312.

9. Omar MK, Rashid AM, Puad MH, Azman AH. Fostering interests for teaching: Job satisfaction and motivation fators of Malaysian TVET instructors, International Journal of Engineering and Technology. 2018; 7(4-9):46-51. https:// doi.org/10.14419/ijet.v7i4.9.20613.

10. Conroy CA. Reinventing career education and recruitment in agricultural education for the 21st century, Journal of Agricultural Education. 2000; 41(4):73-84. https://doi. org/10.5032/jae.2000.04073.

11. Rashid AM, Bakar AR, Asimiran S, Tieng LP. Career development interventions in secondary schools in the state of Terengganu, Malaysia, European Journal of Social Sciences. 2009; 8(1):62-67.

12. Federico CM, Cloud JP, Byrne J, Wheeler K, Orr D. Kindergarten through twelfth-grade education for sustainability, Environmental Law Reporter News and Analysis. 2003; 33(2):10117-31.

13. Feldman RS. Using a small-scale demonstration farm as a teaching arena in biology and environmental science, Journal of College Science Teaching. 1998; 28(3):186-91.

14. Sustainable agriculture and the perceptions of high school agriculture teachers in the North Central Region of the United States. Date accessed: 2006. https://lib.dr.iastate. edu/rtd/1549/.

15. Francis C, King J. Will there be people in sustainable ecosystems? Designing an educational mosaic for the 22nd century, American Journal of Alternative Agriculture. 1994; 9(1-2):16-22. https://doi.org/10.1017/S0889189300005506. 
16. Seufert V, Ramankutty N, Foley JA. Comparing the yields of organic and conventional agriculture, Nature. 2012; 485(7397):229-32. https://doi.org/10.1038/nature11069. PMid: 22535250.

17. Research design: Qualitative, quantitative, and mixed methods approaches. Thousand Oaks, 4th Ed., California:
SAGE Publications; 2014. p. 273. Date accessed: 2017. https://adams.marmot.org/Record/.b40623245.

18. Borsari B, Vidrine MF. Undergraduate agriculture curricula in sustainability: An evaluation across borders, Journal of Sustainable Agriculture. 2005; 25(4):93-112. https://doi. org/10.1300/J064v25n04_08. 